\title{
Dissolution capacity of orange and eucalyptus oils versus endodontic types of cement (in vitro study)
}

\author{
Capacidad de disolución de aceite de naranja y eucalipto frente a cementos \\ endodónticos (estudio in vitro)
}

\author{
Sebastián M. Ulloa-Alvarez ${ }^{\text {a }}$, María E. Guerrero-Coello ${ }^{\text {b }}$, José E. Torracchi-Carrasco ${ }^{\mathrm{c}}$
}

\begin{abstract}
:
Introduction: Endodontic retreatment seeks reentry to the root canal system to remove all filling material, identification and correction of pathological or iatrogenic defects. Objective: This study aimed to compare the dissolving capacity of eucalyptus oil, orange oil, and distilled water versus three types of endodontic cements. Materials and methods: Two hundred and four stainless steel molds were fabricated, where each cement sample was placed to the edge and left to set in the incubator, simulating normal oral conditions for 7 days. Subsequently, the solubility of each cement was analysed by immersing the samples in eucalyptus and orange oil for ten minutes in a static and ultrasonic environment. The solubility of the cement was evidenced by the difference between the weight before and after contact with the oils, data were statistically analysed with the ANOVA test and the post hoc Tukey bootstrap means test with 1,000 repetitions. Results: The control group and eucalyptus oil having no significant effect ( $p>0.05)$, the ultrasonic environment was found to be effective $(\mathrm{p}<0.05)$, whereas orange oil had better dissolution effects $(\mathrm{p}=0.004)$. Conclusions: The most susceptible cement was Sealapex, while the least soluble was MTA-Fillapex in all the solvents studied.
\end{abstract}

Keywords:

Endodontic cement, eucalyptus oil, orange oil, solvents, solubility

\section{Resumen:}

Introducción: El retratamiento endodóntico busca reingreso al sistema de conductos radiculares, remoción de los materiales de relleno, identificación y corrección de defectos patológicos o iatrogénicos. Objetivo: El presente estudio tuvo como objetivo comparar la capacidad disolutiva del aceite de eucalipto, aceite de naranja y agua destilada frente a tres tipos de cementos endodónticos. Materiales y métodos: Se fabricaron doscientos cuatro moldes de acero inoxidable, donde se colocó cada muestra de cemento hasta el borde, se dejaron fraguar en la incubadora, simulando las condiciones bucales normales durante 7 días. Posterior se analizó la solubilidad de cada cemento al sumergir las muestras en aceite de eucalipto y naranja por diez minutos en un ambiente estático y ultrasónico. La solubilidad del cemento se evidenció por medio de la diferencia entre el peso antes y después de tomar contacto con los aceites. Los datos se analizaron estadísticamente con la prueba ANOVA y la prueba post hoc Tukey de medias bootstrap con 1.000 repeticiones. Resultados: El grupo control y el aceite de eucalipto no tuvieron efectos significativos (p>0,05), se evidenció que el ambiente ultrasónico es efectivo ( $\mathrm{p}<0,05)$, mientras que el aceite de naranja tuvo mejores efectos de disolución ( $\mathrm{p}=0,004)$. Conclusiones: El cemento más susceptible resultó ser Sealapex; mientras que el menos soluble fue MTA-Fillapex en todos los solventes estudiados.

\section{Palabras Clave:}

Cemento endodóntico, aceite de eucalipto, aceite de naranja, solventes, solubilidad

\section{INTRODUCTION}

\footnotetext{
${ }^{a}$ General Dental Practitioner, https://orcid.org/0000-0002-4608-9990, Email: odwateo@gmail.com.

b Dentist Specialist in Endodontics, professor of Endodontics in undergraduate courses at the Catholic University of Cuenca, https://orcid.org/0000-0001-5640-9575, Email: mguerreroc@ucacue.edu.ec.

' Research professor at the Faculty of Dentistry of the Catholic University of Cuenca, https://orcid.org/0000-0002-8901-7022, Email: jtorracchic@ucacue.edu.ec.
} 
Endodontic retreatment seeks reentry into the root canals, removal of filling materials, identification and correction of pathological or iatrogenic defects. The elimination of the filling material from the root canal is a sine qua non to conduct retreatment, being thermal, chemical, mechanical, ultrasonic, or a combination of them, the frequent methods to accomplish this. ${ }^{1-3}$ The most commonly utilized obturation material in endodontics is gutta-percha in combination with a variety of sealers cement. This can be removed without difficulty with mechanical methods associated with chemical (solvents); nonetheless, the sealing cement in charge of forming an impermeable barrier in the accessory canals and apical delta, tends to resist dissolution and is more difficult to remove from the root canal. ${ }^{2,4}$ Amongst the most commonly used organic solvents are chloroform, xylol, halothane, eucalyptol, turpentine, and orange oil. Several studies suggest that chloroform is the best solution for dissolving most filling materials since it has a high dissolving capacity compared to others, such as xylol, eucalyptol, and halothane. The U.S. Food and Drug Administration banned its use in 1976 on account of its carcinogenic potential and toxicity to tissues. Conversely, xylol has no carcinogenic potential, although it is toxic to tissues. . $^{3,4-10}$

Both orange and eucalyptol essence oil are said to be a safe alternative with no carcinogenic potential, biocompatible, of low toxicity, and capable of dissolving most types of sealant cement. ${ }^{8,11-13}$ Considering the importance of minimizing the use of traditional solvents such as chloroform or xylol, proven to be harmful to health, and promoting the use of new organic solvents with enhanced clinical safety and timely chemical dissolution capacity, this research aims to compare the dissolution capacity of eucalyptus and orange essential oil versus three types of endodontic cements.

\section{MATERIALS AND METHODS}

The study has a quantitative approach with descriptive scope as phenomena and situations were described, being experimental based on the comparative parameters of variables in laboratory analysis. Three endodontic types of cement (Sealapex®, Tubliseal ${ }^{\circledR}$, and MTA-Fillapex $\left.{ }^{\circledR}\right)$ were utilized together with orange and eucalyptus essential oils (100\% pure). Chemically pure distilled water was used as a non-solvent control group. 204 stainless steel discs with an outer diameter of $10 \mathrm{~mm}$ and a thickness of $3 \mathrm{~mm}$ were fabricated. The central hole is $3 \mathrm{~mm}$, drilled to contain the sealing cement sample, another hole is considered in the periphery to hold the molds when immersed in the solvents. Prior to starting the experiment, the discs were thoroughly cleaned with $90 \%$ alcohol to remove any grease residue. The endodontic cement samples (Sealapex®, Tubliseal ${ }^{\circledR}$, and MTA-Fillapex $\left.{ }^{\circledR}\right)$ were mixed onto the pad provided by the manufacturers, considering the instructions for use. For the test, the discs were filled with cement using a steel spatula. Each disc was taken to the incubator at $37{ }^{\circ} \mathrm{C}$ and $100 \%$ humidity for 7 days until the cement set. At the end of the established period, the discs were removed, the excess material was eliminated from the periphery with a scalpel blade, registering the pre-immersion weight on a digital precision balance "accuracy of 3 thousandths."

For the stationary experimental phase, the discs were immersed for 10 minutes in $10 \mathrm{ml}$ of essence oil; they were then placed in the incubator for 24 hours for drying and final weighing.

In the ultrasonic experimentation phase, the discs were immersed for 10 minutes in $10 \mathrm{ml}$ of essential oil in an ultrasonic washer, whose operating power is $30 \mathrm{~W}$. At the end of the immersion, the samples were placed in the incubator for 24 hours to dry. Subsequently, each disk was weighed on a digital precision balance with similar characteristics as in the previous phase.

\section{Sampling size}

In the case of research that measures a numerical variable in two groups, the sample was calculated utilizing the cluster sampling formula for quantitative variables, with a reliability level of 95\% and an error of $5 \%$.

Where:

$\mathrm{Z} \alpha: 1.96$ constant for $95 \%$ reliability (type I error).

Zß:0.84 constant for $80 \%$ power (type II error).

$\delta$ : Variance of the variable in the control group, reported in reference studies.

$e$ : Difference between the average of group 1 with the average of group 2 obtained through research background.

$n=\frac{2(Z \alpha+Z \beta)^{2} * \delta^{2}}{e^{2}}$

Substituting the formula, we obtain:

$n=\frac{2(1.96+0.84)^{2} * 1.0234^{2}}{1^{2}}=17$

\section{Data analysis}

Data were compared by factorial analysis of variance (ANOVA) and the differences between materials were calculated using multiple comparison tests, performed to statistically identify homogeneous subgroups $(\mathrm{p}<0.05)$ utilizing the post hoc Tukey bootstrap mean test with 1000 replications.

\section{RESULTS}

In the control group, no amount of cement was dissolved; thus, concerning the effectiveness of the environment during cement dissolution, the use of the ultrasonic environment showed results with statistical significance $(\mathrm{p}=0.025)$.

Orange oil was vastly superior in dissolution potential compared to eucalyptus oil ( $\mathrm{p}=0.034)$. The action of orange oil demonstrated to have a better action compared to the control 
group with a value of $(\mathrm{p}=0.004)$. There was no difference between eucalyptus oil and the control group $(\mathrm{p}=0.523)$.

The effect of the different solvents upon the types of cement proved to have a significantly higher loss on Sealapex $(\mathrm{p}=8.637 \mathrm{e}-5)$. When comparing the amount of cement lost between MTA-Fillapex and Sealapex, a more significant loss of the latter was demonstrated $(\mathrm{p}=0.002)$. The control group did not affect MTA-Fillapex $(\mathrm{p}=0.760)$ and Tubliseal $(0.793)$.
The amount of Tubliseal cement lost was not statistically significant when compared to the amount of MTA-Fillapex lost $(\mathrm{p}=1.000)$. The most susceptible cement to dissolution was Sealapex when in contact with the ultrasonically activated orange oil (Figure 1).

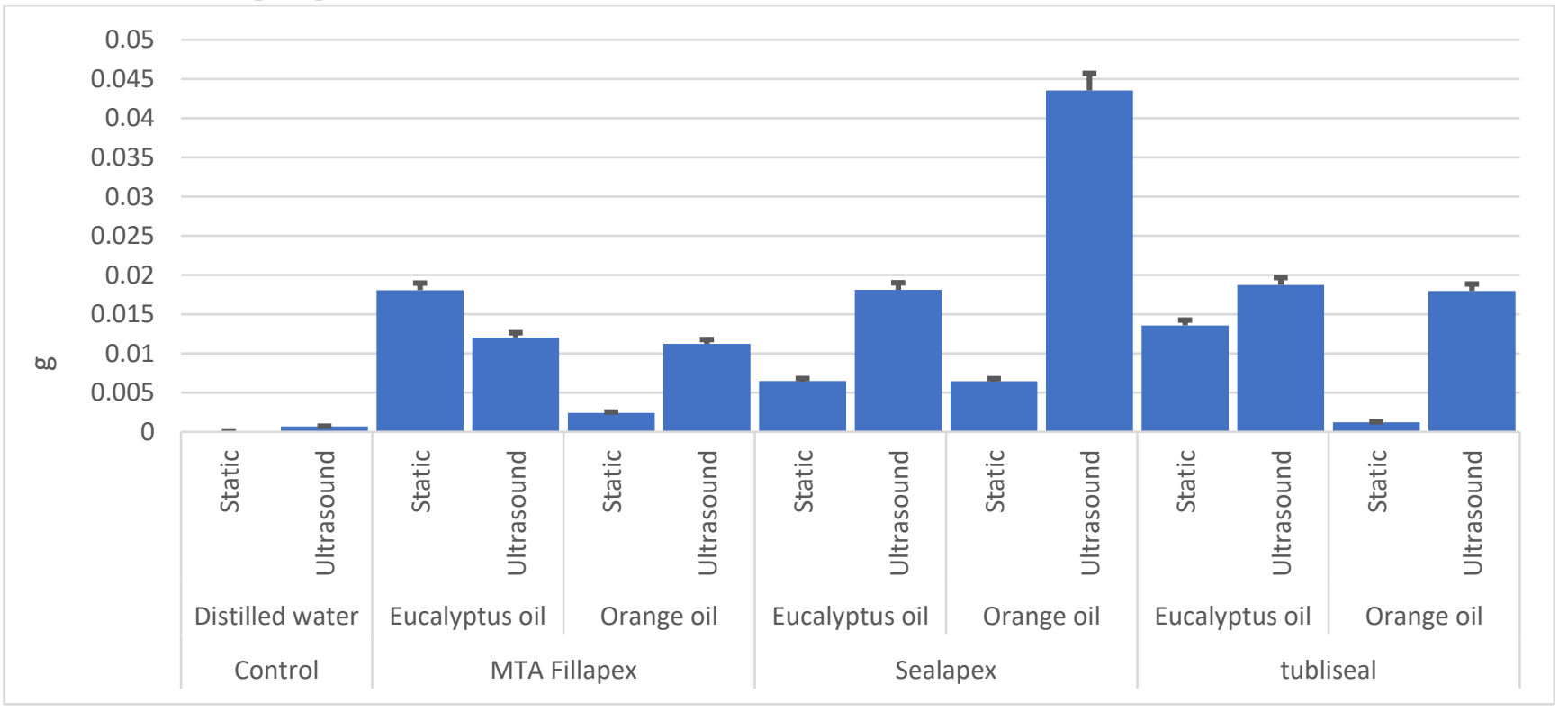

Figure 1. The average dissolving capacity of each of the solvents against all cement and their respective environment.

\section{DISCUSSION}

Non-surgical endodontic retreatment is an effective alternative to apical surgery, though there are always difficulties in its execution. The extent of difficulty of retreatment will depend on the compaction of the gutta-percha in combination with the types of sealing cement. To facilitate the removal of the filling materials, it is advisable to employ methods, such as heat, mechanical action, or solvents. ${ }^{14-16}$

The results of this work showed that the use of solvents as orange oil is effective in the dissolution of the sealer cement $(\mathrm{p}<0.05)$.

Chemical removal of root filling material has been used for more than 100 years since the appearance of chloroform until its prohibition by the FDA due to its carcinogenic potential. Another type of solvent substance is xylol or xylene, which is a volatile solvent with less cytotoxicity than chloroform, however, it represents a risk for personal the health care staff because the vapors irritate mucous membranes, respiratory depression and CNS depression. . $^{3,8,9}$

Essence oils are natural aromatic substances responsible for the fragrances of flowers and other plant organs. They are liquids with low solubility in water, soluble in alcohols, and organic solvents; yet biocompatibility with root canal tissues, orange oil has the highest biocompatibility among the solvents usually utilized and has even been shown to have lower cytotoxicity than eucalyptus oil and chloroform. ${ }^{17,18}$
In this study, the dissolution capacity between orange oil and eucalyptus oil was compared, showing a marked superiority of orange oil $(\mathrm{p}<0.05)$, contrary to studies by authors such as Yadav et al. ${ }^{8}$ where both oils had a similar dissolving capacity on calcium hydroxide-based cement (Apexit Plus) and superior capacity of eucalyptus oil on cement derived from zinc oxide-eugenol (Endomethasone $\mathrm{N})(\mathrm{p}=3.04)(\mathrm{p}<0.05)$, respectively. This disparity in the results may be attributed to the difference in the size of the steel discs or to the manufacturing details of the types of cement, which are not often specified by the manufacturers. As for a study published by Martos et al. ${ }^{2}$ the results coincide with respect to a higher dissolving capacity of orange oil compared to Sealapex (calcium hydroxide base) and Tubliseal (zinc oxide-eugenol base) types of cement.

Orange essence oil is obtained from the remnants of the orange, such as peel, seeds, and pulp. Recently, Tepe et al. investigated the antimicrobial and antioxidant properties. The composition of the oil consists of re-constituents, alcohol, esters, aldehydes, monoterpenes, and sesquiterpenes. ${ }^{19}$

Orange oil is an excellent alternative to the use of potentially toxic solvents to dissolve calcium hydroxide-based and zinc oxide-eugenol-based types of cement as reported in a study published by Mushtaq et al. ${ }^{20}$ where an agreement was found with the present study since the types of cement susceptible to 
orange oil were Sealapex (calcium hydroxide base) and Tubliseal (zinc oxide-eugenol base) $(\mathrm{p}<0.05)$.

In an attempt to minimize the risks produced by chloroform, eucalyptus oil began to be used for its pleasant aroma and null side effects. Nevertheless, Rubino et al. ${ }^{12}$ demonstrated that at room temperature, the dissolution capacity of eucalyptol decreases substantially. The findings agree with this study since the dissolution capacity of eucalyptus oil was low ( $p>0.05$ ) in all the tested types of cement (Sealapex, Tubliseal, MTA-Fillapex).

Eucalyptus oil is extracted from the leaves of the tree itself, which contain up to $3 \%$ pure volatile oil, its active compound, cineol, which is a type of colorless ester that can be soluble in water. $^{21}$

Alzraikat et al. ${ }^{22}$ proved that eucalyptus oil did not present a significant difference in the dissolution of MTA-Fillapex in any type of environment. The low dissolving capacity of eucalyptol coincides with our investigation since the exposure of the oil to a static medium did not produce any kind of movement around the sample that would allow the detachment of the cement from the steel mold. When exposed to an ultrasonic environment, MTA-Fillapex showed little significant solubility, accounting for the fact that during the final weighing stage, it was the cement with the least loss of substance $(\mathrm{p}=0.523)$.

Bayram et al. ${ }^{23}$ examined the dissolving capacity of eucalyptus oil against MTA-Fillapex and Tubliseal for 10 minutes and concluded that eucalyptus oil does not have an adequate dissolving capacity $(\mathrm{p}=3.15)$ and $(\mathrm{p}=2.87)$, respectively. The results are consistent with those presented in this research because Tubliseal and MTA-Fillapex did not show a significant solubility $(\mathrm{p}>0.05)$.

Tanomaru Fihlo et al. demonstrated that the solvent action of eucalyptus oil is effective in zinc oxide-eugenol-based types of cement after 10 minutes. The findings contradict the results of the present study because eucalyptus oil showed a low dissolving capacity compared to Tubliseal $(p>0.05) .{ }^{24}$ The difference in results may be due to differences in experimental methodology; thus, Tanomaru and the team immersed the samples into a solvent for five minutes followed by immersion in distilled water for 20 minutes to counteract the action of the solvent before final weighing. However, in this study, the samples were immersed in each solvent for ten minutes, in addition to not being immersed in distilled water to counteract the effect of the solvent before final weighing.

The agitation effect during ultrasonic activation is shown by the vibrations seen in the liquid surrounding the cement samples. When talking about the adhesion of the cement to the root canal walls, the bonding conditions affect the degree of dissolution by ultrasonic agitation. ${ }^{22}$ Solvent agitation resulted in superior dissolution power of the ultrasonic environment over the static environment $(\mathrm{p}=0.025)$.

The loss of sealing cement increases with the exposure time to the solvent. Therefore, the selected interval of 10 minutes was effective, according to studies published by Alzraikat (22), where the solubility of the cement is higher -if the immersion time increases from 5 to 10 minutes-. Martos ${ }^{2}$ evaluated immersion intervals of 2 and 10 minutes and showed that Intrafill (zinc oxide-eugenol base) had a more pronounced solubility after 10 minutes of immersion in all the solvents tested $(p<0.05)$. Furthermore, it was found that the calcium hydroxide-based cement did not show a significant loss of mass during both periods, although it presented the highest disintegration value in orange oil $(\mathrm{p}<0.05)$, followed by eucalyptus oil. Yadav $^{8}$ evidenced a study in which he compared the solubility of two types of cement immersed in essence oils (orange and eucalyptus) and obtained results where both Apexit Plus (calcium hydroxide base) and Endomethasone N (zinc oxide-eugenol base) dissolved in greater quantity during 10 minutes compared to 2 minutes $(\mathrm{p}<0.001)$.

Regarding water absorption during the setting period, Loushine et al. determined that water absorption is essential for MTA Fillapex to reach full set because the inorganic components of the sealant are pre-mixed with water-free liquid thickener matrices, indeed, the manufacturer suggests that setting times are longer in excessively dry ducts. ${ }^{25}$

In endodontic types of cement composed by zinc oxide and eugenol, Branstetter reported that the probability that water could be absorbed by the sealer or degrade it, thus affecting the solubility results. These changes are related to the dimensional stability of the sealer. ${ }^{26}$

This study also addressed certain ideal conditions for the success of the research, such as the use of an incubator at a temperature of $37^{\circ} \mathrm{C}$ that simulates normal oral conditions; the samples selected were those in which the cement surface is not penetrated by a dental explorer, and both static and ultrasonic environments were tested.

The decision of an ideal solvent during retreatment requires a balance between the level of clinical safety, the level of toxicity and aggressiveness towards tissues, as well as its chemical dissolution capacity.

\section{CONCLUSIONS}

Within the limitations of this laboratory research, we can conclude that:

Orange oil has a much higher dissolution potential than eucalyptus oil, therefore, eucalyptus oil is not an effective solvent in the cleaning of root system ramifications in clinical practice.

Ultrasonic activation of the solvent will provide better dissolution results owing to the vibrations exerted on the surface of the cement, favoring its detachment.

In terms of the solubility of the types of cement, Sealapex was the most susceptible, followed by Tubliseal, whereas MTAFillapex was the least soluble cement. 


\section{Conflict of interest}

No conflict of interest between the authors during the development of this research was encountered.

\section{REFERENCES}

[1] Herrera-Plascencia P, García-Rupaya C, Delgado-Cotrina L. Eficacia disolvente y citotoxicidad del aceite de cáscara de limón (Citurs limon). Rev. Estomatol. Herediana. 2019;29: 196-202.

[2] Martos J, Gastal MT, Sommer L, Lund RG, Del Pino FAB, Osinaga PWR. Dissolving efficacy of organic solvents on root canal sealers. Clin. Oral Invest. 2006; 10: 50-4.

[3] Pineda-Mejía M, Palacios-Alva E, Terán-Casafranca L., NúñezLizárraga M, Gloria-Zevallos W, Abuhadba-Hoyos T. Evaluación in vitro de tres solventes de gutapercha. Odontol. Sanmarquina. 2011; 14:15-28.

[4] Bodrumlu E, Er O, Kayaoglu G. Solubility of root canal sealers with different organic solvents. Oral. Surg. Oral. Med. Oral. Pathol. Oral. Radiol. Endod. 2008; 106: 67-9.

[5] Johnson WT, Kulid JC. Obturación del sistema de conductos radiculares limpios y conformados. In: Hargreaves KM, Cohen S, Berman LH, editors. Vías de la pulpa. 10th ed. Barcelona: Elsevier Masson; 2011.

[6] Glickman GN, Walton RE. Obturación. In: Torabinejad M, Walton RE, editors. Endodoncia: Principios y Práctica. 4th ed. Barcelona: Elsevier Masson; 2010.

[7] Canalda-Sahli C. Obturación de los conductos radiculares. In: Canalda C, Brau-Aguadé E, editors. Endodoncia: Técnicas clínicas y bases científicas. 3rd ed. Barcelona: Elsevier Masson; 2014.

[8] Yadav-Kumar H, Yadav-Kumar R, Chandra A, Rameshbhai-Thakkar R. The effectiveness of eucalyptus oil, orange oil, and xylene in dissolving different endodontic sealers. J. Conserv. Dent. 2016; 19: 332-37.

[9] Nagayama Oyama KO, Siqueira EL, dos Santos M. In Vitro Study of Effect of Solvent on Root Canal Treatment. Braz. Dent. J. 2002; 13: 208-11.

[10] Vinothkumar-Thrilla S, Deivanayagam K, Ganesh A, Kumar D. Influence of different organic solvents on the degree of swelling of poly (dimethylsiloxane)-based sealer. J. Conserv. Dent. 2011;14:15659.

[11] Faria-Júnior NB, Loiola LE, Guerreiro-Tanoumaro JM, BerbertVillela FL, Tanoumaro-Fihlo M. Effectiveness of Three Solvents and Two Associations of Solvents on Gutta-Percha and Resilon. Braz. Dent. J. 2011;22: 41-4.

[12] Rubino G, Akisue E, Nunes B, Gavini G. Solvency capacity of guttapercha and Resilon using chloroform, eucalyptol, orange oil, or xylene. J. Health. Sci. Inst. 2012; 30(1). 22-5.

[13] Parviz-Aberoomand A, Mehdi N, Kambiz L, Sakineh B. Chemical composition of the essential oils of Citrus sinensis cv, Valencia and a quantitive structure-retention relationship study for the prediction of retention indices by multiple linear regression. J. Serb. Chem. Soc. 2011; 76(12): 1627-37.

[14] Hartwell G. Retratamiento no quirúrgico. In: Torabinejad M, Walton RE, editors. Endodoncia: Principios y Práctica. 4th ed. Barcelona: Elsevier Masson; 2010.

[15] Canalda-Sahli C, Suñé-Pumarola J. Retratamiento no quirúrgico de los fracasos endodónticos. En: Canalda C, Brau-Aguadé E, editors. Endodoncia: Técnicas y bases científicas. 3rd ed. Barcelona: Elsevier Masson, 2014.

[16] Roda R, Gettleman B. Retratamiento no quirúrgico. In: Hargreaves KM, Cohen S, Berman LH, editors. Vías de la pulpa. 10th ed. Barcelona: Elsevier Masson; 2011.
[17] López-Luengo MT. Los Aceites Esenciales: Aplicaciones farmacológicas, cosméticas y alimentarias. Offarm. 2004;23:88-91.

[18] Khedmat S, Hasemi A, Dibaji F, Kharrazifard MJ. Effect of Chloroform, Eucalyptol, and Orange Oil Solvents on the Microhardness of Human Root Dentin. J. Dent. 2015;12:25-30.

[19] Kamal GM, Anwar F, Hussain AI, Sarri N, Ashraf MY. Yield and chemical composition of Citrus essential oils as affected by drying pretreatment of peels. Int. Food. Res. J. 2011;18:1275-82.

[20] Mushtaq M, Masoodi A, Farooq R, Khan-Fayiza Y. The Dissolving Ability of Different Organic Solvents on Three Different Root Canal Sealers: In Vitro Study. IEJ. 2012;7:198-02.

[21] Astaq-Mohal K, Seatara K, Hossain MK, Rahman L. Characterization of the eucalyptus (e. Globulus) leaves oil. J. Bangladesh. Chem. Soc. 2012;25:97-100.

[22] Alzraikat H, Taha NA, Hassouneh L. Dissolution of a mineral trioxide aggregate sealer in endodontic solvents compared to conventional sealers. Braz. Oral. Res. 2015;30:1-8.

[23] Bayram E, Dalat D, Bayram M. Solubility Evaluation of Different Root Canal Sealing Materials. J. Contemp. Dent. Pract. 2015;16:96100.

[24] Tanomaru-Fihlo M, Orlando T, Bortoluzzi EA, da Silva GF, Tanomaru-Guerreiro JM. Solvent capacity of different substances on gutta-percha and Resilon. Braz. Dent. J. 2010;21:46-9.

[25] Loushine BA, Bryan TE, Looney SW, et al. Setting properties and cytotoxicity evaluation of a premixed Bioceramic root canal sealer. J. Endod. 2011;37:673-77.

[26] Branstetter J, von Fraunhofer JA. The physical properties and sealing action of endodontic sealer cements: a review of the literature. J. Endod. 1982;8:312-16. 